\title{
A Novel Approach for Estimating the Recurrence Intervals of Channel-Forming Discharges
}

\author{
Andy Ward ${ }^{1, *}$ and Molly Moran ${ }^{2}$ \\ 1 Department of Food, Agricultural and Biological Engineering, The Ohio State University, Columbus, \\ OH 43210, USA \\ 2 Department of Civil, Environmental and Geodetic Engineering, The Ohio State University, Columbus, \\ $\mathrm{OH}$ 43210, USA; moran.222@osu.edu \\ * Correspondence: ward.2@osu.edu; Tel.: +1-614-292-9354
}

Academic Editor: Athanasios Loukas

Received: 17 February 2016; Accepted: 21 June 2016; Published: 28 June 2016

\begin{abstract}
Channel-forming discharges typically are associated with recurrence intervals less than five years and usually less than two years. However, the actual frequency of occurrence of these discharges is often several times more frequent than the statistical expectation. This result was confirmed by using the Log-Pearson Type 3 statistical method to analyze measured annual series of instantaneous peaks and peak daily means for 150 catchments in six states in the North Central Region of the United States. Discharge records ranged from 39 to 102 years and catchment sizes ranged from 29 to $6475 \mathrm{~km}^{2}$. For each state, mean values of the ratio of the calculated to the expected occurrences exceeded 1.0, for recurrence intervals from two years to 100 years with R-squared values varying from 0.64 to 0.97 , respectively. However, catchment-by-catchment variability was too large for the relationships for each state to be useful. We propose a method, called Full Daily Distribution (FDD), which used all of the daily values for the available period of records. The approach provided ratios of calculated to expected occurrences that were approximately 1.0. For recurrence intervals less than five years, the FDD calculated discharges were much greater than those obtained by using the Log-Pearson Type 3 approach with annual series of instantaneous peaks or peak daily means. The method can also calculate discharges for recurrence intervals less than one year. The study indicates a need to enhance the Log-Pearson Type 3 method to provide better estimates of channel-forming discharges and that the proposed FDD could be a useful tool to this purpose.
\end{abstract}

Keywords: channel-forming discharges; Log-Pearson Type 3; annual series of peaks; probability density function; annual occurrences; river restoration

\section{Introduction}

Based on an analysis of the 37,099 projects in the National River Restoration Science Synthesis (NRRSS) database, Bernhardt et al. [1] estimated that annual expenditures on stream restoration in the United States exceeded one billion dollars and was increasing exponentially. They identified the most common goals of river restoration as enhancing water quality; managing riparian zones; and improving in-stream habitat and improving fish passage and stabilizing banks. A concern they identified a decade ago was that most small- to modest-sized projects had no post-construction monitoring or assessment of performance, therefore limiting our ability to know if our efforts approximated a river's remaining natural potential and to learn from successes and failures. Since the mid-1990s, the controversial Natural Channel Design approach that was developed by Dave Rosgen has seen widespread application in the United States [2-4]. The backbone of the approach is a classification system that depended on knowledge of bankfull discharges. Simon et al. [5] argued that a fundamental problem with the approach was that it was based on channel form and did not adequately consider 
channel processes. We will not jump into this debate, but we concur with Simon et al. that identifying and measuring the bankfull geometry in order to ascertain bankfull discharges is often difficult in an unstable stream system and that it is desirable to collect geotechnical data to help evaluate bank stability. Channel processes include the knowledge of channel-forming or dominant discharges and are often the foundation of river restoration projects [6]. In this manuscript, we use the term channel-forming discharge to designate either the bankfull $\left(Q_{b}\right)$ or effective discharge $\left(Q_{e}\right)$.

Wolman and Miller [7] described the bankfull discharge as the stream-flow that filled the main channel and that began to spill onto the active floodplain; while the effective discharge was the discharge that transported the most sediment over time. Goodwin [8] provided a useful study on what he called the dominant discharge that determined the cross-sectional and planform characteristics of a channel, and he noted that the dominant discharge could be based on measurements, the effective discharge, or the recurrence interval (RI) of the dominant discharge. Doyle et al. [6] stated that the bankfull discharge, or a discharge for a user-specified recurrence interval, was used widely in design procedures without consideration of the effective discharge. Although the bankfull and effective discharge were each considered to be channel-forming discharges, they are not identical. For example, Emmitt and Wolman [9] reported that the ratio of the effective discharge to bankfull discharge, $Q_{e} / Q_{b}$, ranged from 0.98 to 1.31 for five gravel-bed streams in the northern Rocky Mountains, USA. Torizzo and Pitlick [10], also in the Rocky Mountains, found that $Q_{e} / Q_{b}$ ranged from 0.8 to 1.5 for 12 gravel-bed streams. Powell et al. [11] found that the $Q_{e} / Q_{b}$ ratio ranged from 0.4 to 2.5 for 10 large rivers in Ohio. Channel-forming discharges have often been associated with a fixed recurrence interval such as 1.5 or 1.58 years [12], which were partially derived from the classic work of Leopold et al. [13]; however, studies also warn against using a fixed recurrence interval [14].

One method for determining the effective discharge is the Wolman-Miller Model [15], which Powell et al. [11] illustrated for the Maumee River in Ohio at a United States Geological Survey (USGS) gauge having a catchment area of $16,395 \mathrm{~km}^{2}$ (Figure 1). In this study, 43 years of discharge and suspended-sediment data were divided into $100-\mathrm{m}^{3} / \mathrm{s}$ discharge ranges (bins) starting with 0 to $100 \mathrm{~m}^{3} / \mathrm{s}, 100+$ to $200 \mathrm{~m}^{3} / \mathrm{s}, 200+$ to $300 \mathrm{~m}^{3} / \mathrm{s}$, and so forth until a final bin was made that contained all data for discharges larger than $2700 \mathrm{~m}^{3} / \mathrm{s}$. The total sediment load per bin (solid line) was the product of the two dashed lines (days in a particular bin multiplied by the average daily load for discharges in the bin). Low discharges were ineffective in transporting sediment, and extreme events had very high sediment transport rates but occurred infrequently so the total sediment load they carried over a period of many decades was not the bin with the largest average discharge.

For the result shown in Figure 1, the effective discharge was about $700 \mathrm{~m}^{3} / \mathrm{s}$; however, there were two potential issues with this approach. First, at a particular gauge, there might be considerable variability in the calculated effective discharge, as it will vary with the flow range of the bin. Powell et al. [11] illustrated this concept for the Maumee River by reporting larger estimates of the effective discharge, in part, because wash loads were excluded and perhaps because the bins were sized based on stage increments rather than discharge increments. Simon et al. [16] stated that mean daily values of both flow and sediment loads, which were readily available from the USGS, tended to be biased towards lower flows, particularly in flashy basins. They noted that using data at shorter time increments was best but that type of measured data was seldom available. Second, in addition to the lack of a standard approach to determining bin sizes for an effective discharge analysis, the approach sometimes gave more than one peak (effective) discharge. This might be an anomaly of the analysis but also could be the geomorphic reality [17]. 


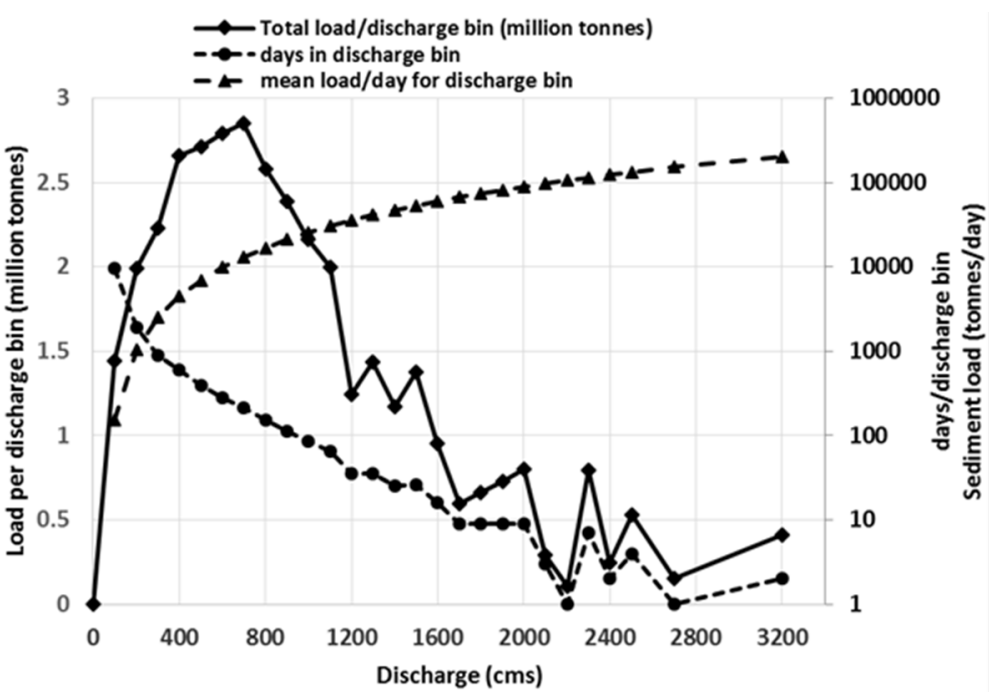

Figure 1. Illustration for the Maumee River, Ohio, that the effective discharge, $700 \mathrm{~m}^{3} / \mathrm{s}$, carries the largest total sediment load based on 14,415 days of discharge and suspended load data from 1950 to $1993\left(\mathrm{cms}=\mathrm{m}^{3} / \mathrm{s}\right)$. Powell et al. [11].

Useful guidelines on determining the effective discharge have been published by Biedenharn et al. [18]. Other approaches to determining the effective discharge included using a sediment transport threshold, such as the discharge that transported $50 \%$ of the sediment, to quantify the channel-forming discharge [19,20]. For large rivers in Ohio, Powell et al. [11] found the ratio of the threshold discharge, associated with transport of $50 \%$ of the sediment, to the bankfull discharge was 0.5 to 1.8. Powell et al. [11] reported that the effective discharge and bankfull discharge often had RIs of less than one year; however, they also found that even in rivers with RIs of at least a year the channel-forming discharges, or large discharges, occurred 1 to 24 days a year. Their results were not unique and were in contradiction not only with statistical expectations but also numerous studies in the literature [5,6,21]. Nolan et al. [22] found that discharges, which transported $50 \%$ to $90 \%$ of the sediment load, had recurrence intervals (RIs) of 0.27 to 16.1 years. Andrew and Nankervis [15] and Sichingabula [23] reported discharges that transported $50 \%$ to $80 \%$ of the sediment load to have flow durations of 11 to 80 days annually.

For headwater rivers in Idaho, Whiting et al. [24] reported RIs of 1.0 to 2.8 years for the effective discharge. In a study in the northern Rocky Mountains, Emmett and Wolman [9] reported RIs ranging from 1.5 to 1.7 years, while MacRae [25] reported RIs of 1.6 to 10 years for a study in British Columbia. Andrews and Nankervis [15] described the effective discharge as that which transports the largest portion of the mean annual bed-material load over time, and in the gravel bed rivers located in mountainous parts of Colorado, they found that $80 \%$ of the mean annual load was transported by flows between 0.8 to 1.6 times the bankfull discharge, which on average occurred as 15.6 events per year.

Gomez et al. [26], in a study of a gravel-bed river in New Zealand, estimated that the average RI of the effective discharge was $4 \pm 2$ years but it was equaled or exceeded three times a year. In a study of 12 urban river channels in southern Ontario, Canada, Annable et al. [27] reported that bankfull discharge occurred more than once a year in all of the rivers, often averaged from four to eight bankfull discharge or larger events per year, and in one case 18 events occurred in a year. Other examples of channel-forming discharges occurring many times annually include: Andrews [28], who reported effective discharge flow duration values of 1.5 to 11 days annually, with corresponding recurrence intervals of 3.26 and 1.18 years, respectively; and Wolman and Miller [7], who reported channel-forming discharge or larger of 6 to 11 days per year.

Numerous studies and methods have been used to develop relationships between discharge and RI, but much focus has been on applying these methods to extreme floods. Common approaches 
that are used to analyze river discharge data are based on: (1) an analysis of an annual series of peak values; (2) a partial duration or peaks over threshold approach; (3) an analysis of a probability density function; and (4) an annual frequency of exceedance approach. In the United States, the most commonly used method by state and federal agencies is the Log-Pearson Type 3 statistical method and procedures [28-31]. As the main purpose of the Log-Pearson Type 3 statistical method was to identify probable maximum discharges and flood elevations, it is usually used with an annual series of "instantaneous" peak values-a series of the highest discharge in each year that was recorded at an interval of 5 to $60 \mathrm{~min}$ depending on the river. The main disadvantage of using an annual series is that it excludes large floods when several occur in a single year [32].

Using a partial duration series, also called peaks over threshold approach, to determine the RI has also seen much application [33-39]. For frequent floods, it is the recommended method as it provides better estimates than the annual series of peaks approach [38]. The main problem with the peaks over threshold approach is determining the threshold to be used.

Logic and methods based on sediment transport, such as the effective discharge or half-load discharge [40], suggest that using a continuous series of discharges should be used to determine channel-forming discharges. If a continuous series of data is not available, such as discharge values every $15 \mathrm{~min}$, an approach commonly used is to develop histograms and probability density functions (pdf) based on mean daily discharge data. There is much variability in how different scientists have developed strategies on how to perform this type of analysis. Doyle et al. [41] divided a histogram into 25 bins to represent the pdf of the daily discharge. Crowder and Knapp [42] used an iterative approach to reducing the number of bins from 25 until each bin had at least one discharge value. In addition to a lack of a standard approach to determining the bin size, the main drawback of a pdf approach is that the magnitude of the largest calculated RI is the number of years of available data. Determining the annual frequency of exceedance, for example, of specified mean daily discharge can be obtained from a histogram based on an annual series of mean daily discharges—or values associated with other time increments such as $15 \mathrm{~min}$. In order to maximize the stability of channel reaches, channel-forming discharge is usually adopted as the design discharge in channel design and restoration [6].

We have cited just a few of the many studies that consider the annual frequency of occurrence of channel-forming discharges. The problems with the approach and its usefulness in river restoration are in knowing that a channel-forming discharge or larger occurs a certain number of times annually. Quader and Guo [43] warned that an inaccurate estimation of the design discharge in river restoration could adversely affect project performance. Amongst others, Doyle et al. [6] also noted that one should not just rely on return intervals or bankfull discharges in river restoration designs.

The goal of our study was to address statistical inconsistencies in the range of channel-forming discharges using 150 case studies across six states in the North Central Region of the United States, and to propose a novel, alternative approach to determining discharge versus RIs based on daily values rather than peak values, which we call the Full Daily Distribution (FDD). Specific objectives of our study were to: (1) determine the annual frequency of occurrence of daily discharges ranging from 2 to 100 years with particular focus on discharges with a RI of 10 years or less by comparing a simplified Log-Pearson Type 3 method to the more sophisticated method commonly used for USGS gauged sites; (2) determine if our method of calculating annual frequency of occurrences using mean daily values was consistent with statistical probability expectations; and (3) evaluate the appropriateness of the use of the new FDD approach to determine discharge versus RI relationships.

\section{Materials and Methods}

\subsection{Study Site Selection}

The study was conducted by using USGS surface water gauge data for six states located in the North Central Region of the United States that are within the Mississippi River Basin and the Great Lakes Region (see Figure 2). 


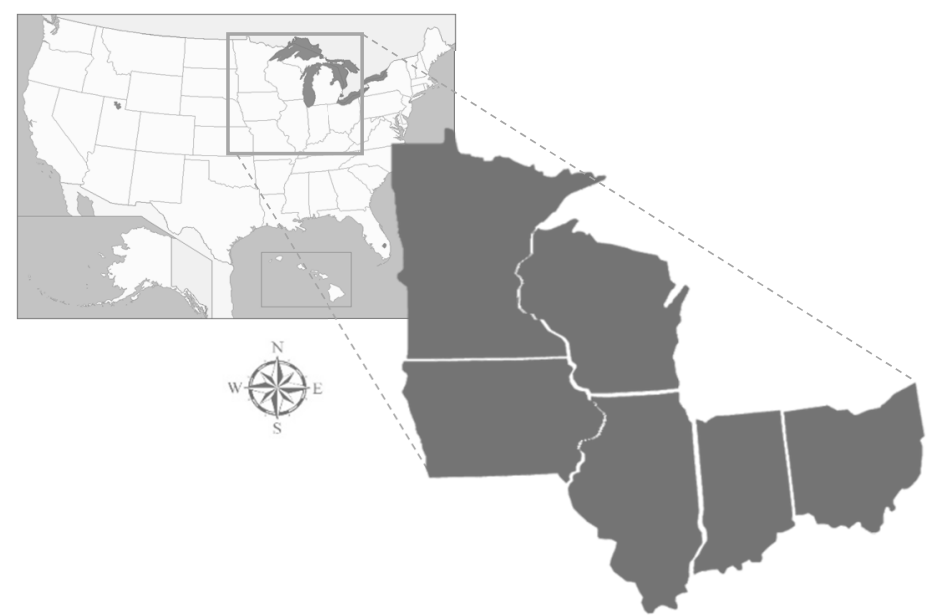

Figure 2. The six states from the North Central Region of the United States that were used in this study.

The data used in the study was obtained from the USGS-NWIS website (http:/ / waterdata.usgs. gov/nwis). For each state, we searched gauges for mean daily and instantaneous peak surface water data that had a minimum of 14,610 days (or 40 years) in the period of record. We excluded the catchments where there was evidence on maps on the NWIS website of large lakes and dams. We then looked for the most recent published surface water discharge values for unregulated streams in each state (Table 1). In order to have a common comparison between sites, we included only rivers that had published estimates using the Log-Pearson Type 3 method in the data set. Published unregulated river discharge values are reported as peak discharges and were calculated using a Log-Pearson Type 3 method that considers the skew [33]. We compared unregulated sites listed in the publications with sites we selected visually. If we had a site in our data set that was not listed in the publication it was removed. The most recent publication for Indiana did not report the 2-year and 5-year recurrence interval discharge values so those values were not included in our study.

Table 1. Publications with discharge versus recurrence interval data for the 150 rivers evaluated.

\begin{tabular}{ccc}
\hline State & Authors & Scientific Report \\
\hline Illinois & Soong et al. [44] & USGS 2004-5103 \\
Indiana & Knipe and Rao [45] & FHWA/IN/JTRP-2005/1** \\
Iowa & Eash et al. [46] & USGS 2013-5086 \\
Minnesota & Lorenz et al. [47] & USGS 2009-5250 \\
Ohio & Koltun [48] & USGS 03-4164 \\
Wisconsin & Walker and Krug [49] & USGS 03-4250 \\
\hline
\end{tabular}

Note: ** Joint Transportation Research Program (Federal, Indiana and U.S. Highway Administration).

We used a second approach to determine if a gauge site was regulated or unregulated to help further reduce the data set. In that approach, we determined the number of times the daily discharge event occurred or was exceeded for a given recurrence interval for the period of record and normalized the occurrence of daily discharge events so that every site provided calculated results for 100-year time periods. For example, if a recurrence interval event was met or exceeded 32 times for a gauge with 40 years of data the result was normalized to 80 times in 100 years (32 times 100 divided by 40). If 100 -year events at a site occurred five times more often than the expected statistical probability, that was an indicator that it might have been a regulated river and it was removed from the data set. 


\subsection{Data Analysis}

\subsubsection{Comparison of Discharge versus Recurrence Interval Relationships}

Using Microsoft Excel spreadsheet software and analysis tools we developed, we performed Objectives 1 and 2 using the following 6-part method for each catchment. First, for each catchment, we downloaded annual series of "instantaneous" peak discharges and daily mean discharge data for the period of record. We then used a pivot table to determine the peak daily mean discharge in each year of the period of record. Third, we developed discharge versus recurrence interval relationships for the period of record using HydroToolBox, a Microsoft Excel add-on that provides specialized functions for commonly used hydrology analyses including determining recurrence intervals from an annual series of discharge data using a simplified Log-Pearson Type 3 method. We used the HydroToolBox to develop annual "instantaneous" and daily discharge versus recurrence interval relationships for the 2-year, 5-year, 10-year, 25-year, 50-year, and 100-year recurrence intervals at each site.

Fourth, we determined the number of times discharges associated with a particular recurrence interval were exceeded. Fifth, because periods of record varied between sites we chose to normalize the data to provide an estimate of the number of days in a 100-year time period a particular discharge might be exceeded. To do this, the calculated number of exceedances were multiplied by 100 divided by the period of record expressed in years.

Sixth, a second Excel analysis tool was used to calculate the number of times during the period of record that $75 \%$ and $125 \%$ of the annual peak daily mean discharge values, associated with a particular recurrence interval were exceeded. To do this, we took the annual peak daily mean values of each site from Step 1 and multiplied them by 75\% and 125\%, respectively. We then repeated Steps 2 and 3 to obtain our final calculated values. The purpose of Step 6 was to account for estimation errors associated with the period of record and because our simplified Log-Pearson Type 3 model did not vary the skew on the data. Based on the work of McCuen and Galloway [33], the plus or minus 25\% range should account for the expected uncertainty in most estimates of the smaller 2-year, 5-year and 10-year recurrence interval discharges.

Last, we checked for errors in our simplified Log-Pearson Type 3 discharge estimates (herein referred to as "calculated") by comparing the results to results published in the documents listed earlier in Table 1.

\subsubsection{Determining Full Daily Distribution (FDD)}

We developed an Excel analysis tool to determine a Full Daily Distribution (FDD) for each gauge. The premise of the FDD is that it uses the whole period of record for a given site, but adjusts the bin size as a function of both the period of record and the maximum discharge of the data series. The FDD approach we developed provided a method for determining a bin size whose magnitude was related to the period of record. The FDD tool required importing mean daily discharge data from the USGS-NWIS website for each study site, ranking the discharge values from highest to lowest, and then dividing the data into bin sizes determined with the following equation:

$$
Q_{b i n}=Q_{\max } / K Y
$$

where $Q_{b i n}$ is the bin discharge range, $Q_{\max }$ is the highest daily discharge in the series, $Y$ is the number of years in the period of record, and $K$ is a user-defined number. We developed this approach so the bin size increment for each gauge would vary as a function of the maximum daily discharge rather than using a fixed discharge such as $1 \mathrm{~m}^{3} / \mathrm{s}$. The number of bins, $n$, for a catchment was $Q_{\max } / Q_{\text {bin }}$ or KY. Non-numeric discharge entries, such as an "ice" notation and missing data in the downloaded daily mean discharges were assigned a discharge value of $0 \mathrm{~m}^{3} / \mathrm{s}$. Typically, there were 0 to 150 days where we made this correction and most catchments did not have any non-numeric entries. In this study, a value of 20 was used for $K$. 
The Excel tool used the following procedure: (1) the downloaded data were ranked from highest to lowest; (2) Equation (1) was used to determine the bin size increment and then $\mathrm{n}$ bins were created with sizes incrementally increasing from $Q_{b i n}$ to $n Q_{b i n}$; (3) the histogram function in Excel was used to populate the bins and to determine the number of discharge occurrences in each bin; (4) the cumulative number of occurrences was determined starting with the bin with the largest discharges and ending with the bin with the smallest discharges; and (4) the occurrence interval of each bin size was calculated as the period of record $Y$ divided by the cumulative number of occurrences. The statistical number of occurrences, $O s$, was determined as $Y / R I$ and calculated results were then determined for recurrence intervals that were closest to 0.8-years, 1-year, 1.4-years, 2-years, 5-years, 10-years, 25-years, 50-years, and 100-years.

\subsubsection{Analysis of Results}

The focus for Objectives 1 and 2 was evaluating whether the Log-Pearson Type 3 approach provided reasonable estimates of discharges associated with recurrence intervals up to 100 years. Of particular interest were discharges for recurrence intervals less than 10 years. There is no scientific method to measure these relationships so the analysis was based on calculated versus expected number of occurrence of different magnitude, or larger, discharges in 100 years. For the 2-year, 5-year, 10-year, 25-year, 50-year, and 100-year RIs the number of occurrences in 100 years would be 50, 10, 4, 2, and 1, respectively. For example, a 10-year or larger discharge is expected to occur on average 10 times. The expected value of 10 would consist of all discharges equal or larger than the 10-year discharge. This analysis was done with the results from the Log-Pearson Type 3 approach with the annual series of peak daily discharges. A meaningful analysis could not be done with the annual series of "instantaneous" peak data because only one value per year is available in the USGS-NWIS database.

The calculated number of occurrences were divided by the expected number of occurrences for each catchment and the recurrence intervals previously listed. Mean and standard deviations of these ratios were then determined for all catchments in the dataset and for the catchments located in each state. Step 5 in Section 2.2.1 was used in a similar way to determine means and standard deviations for ratios based on $75 \%$ and $125 \%$ of the discharges obtained with the Log-Pearson Type 3 approach. Regression relationships were determined between the occurrence ratios and recurrence intervals for the mean of the catchments for each state and the mean value for all catchments in the dataset.

Last, we compared our calculated Log-Pearson Type 3 discharge versus recurrence interval results, based on the annual "instantaneous" peak discharge series, to results published in the documents listed in Table 1. In this case, "instantaneous" peak data were used because comprehensive results based on an annual series of daily peak data were not found in the literature.

For Objective 3, ratios of the discharge versus recurrence interval values, determined with the FDD method, were compared to discharges calculated using the Log-Pearson Type 3 method with both the annual series of "instantaneous" peak discharges and the annual series of daily peak discharges. To calculate these ratios it was first necessary to obtain logarithmic regression relationship between discharge and recurrence intervals for values obtained with the Log-Pearson Type 3 results. This was done because, with the FDD approach, it was not possible to calculate results for the specific recurrence intervals of 2-year, 5-year, 10-year, 25-year, 50-year and 100-year recurrence intervals used for the Objective 1 and 2 analysis. Also, with the FDD approach, there was variability in the calculated recurrence intervals for each catchment. The form of these relationships was:

$$
Q=\mathrm{aln} R I+\mathrm{b}
$$

where $Q$ is the discharge $\left(\mathrm{m}^{3} / \mathrm{s}\right), R I$ is the recurrence interval (years) and $\mathrm{a}$ and $\mathrm{b}$ are regression coefficients.

The use of logarithmic regression relationships with the Log-Pearson Type 3 data facilitated obtaining calculated results for recurrence intervals less than 1 year. 


\section{Results}

\subsection{Site Selection}

The average discharge record used in the analysis ranged from 68 years in Indiana to 79 years in Illinois (Table 2). There was one gauge in Minnesota with a recurrence interval less than 40 years. This was due to difficulty in finding rivers with long discharge records that did not contain numerous lakes and dams. The final dataset consisted of 150 catchments with 25 catchments located in each state. Catchment areas ranged from $29 \mathrm{~km}^{2}$ to $6475 \mathrm{~km}^{2}$. Of the 150 gauges used in the analysis, 12 had a catchment area smaller than $200 \mathrm{~km}^{2}$, while 76 and 15 had catchment areas larger than $1000 \mathrm{~km}^{2}$ and $3000 \mathrm{~km}^{2}$, respectively.

Table 2. Average Annual Precipitation, Discharge and Catchment Area Data for 25 rivers in each of the six states.

\begin{tabular}{cccccccc}
\hline State & $\begin{array}{c}\text { Annual } \\
\text { Rainfall } \\
\mathbf{( m m )}\end{array}$ & $\begin{array}{c}\text { Average } \\
\text { Discharge } \\
\text { Record } \\
\text { (Years) }\end{array}$ & $\begin{array}{c}\text { Minimum } \\
\text { Discharge } \\
\text { Record } \\
\text { (Years) }\end{array}$ & $\begin{array}{c}\text { Maximum } \\
\text { Discharge } \\
\text { Record } \\
\text { (Years) }\end{array}$ & $\begin{array}{c}\text { Average } \\
\text { Catchment } \\
\text { Area } \\
\left.\mathbf{( k m}^{\mathbf{2}}\right)\end{array}$ & $\begin{array}{c}\text { Minimum } \\
\text { Catchment } \\
\text { Area } \\
\left.\mathbf{( k m}^{\mathbf{2}}\right)\end{array}$ & $\begin{array}{c}\text { Maximum } \\
\text { Catchment } \\
\text { Area } \\
\left.\mathbf{( k m}^{\mathbf{2}}\right)\end{array}$ \\
\hline Illinois & 996 & 80 & 46 & 101 & 1520 & 29 & 5416 \\
Indiana & 1060 & 68 & 52 & 86 & 1104 & 222 & 2222 \\
Iowa & 864 & 69 & 43 & 102 & 1772 & 66 & 6475 \\
Minnesota & 693 & 69 & 39 & 93 & 1657 & 363 & 4869 \\
Ohio & 993 & 74 & 51 & 100 & 896 & 158 & 3240 \\
Wisconsin & 829 & 77 & 40 & 101 & 982 & 47 & 2678 \\
\hline
\end{tabular}

\subsection{Objective 1: Annual Frequency of Occurrences of Daily Discharges}

A summary of the calculated number of daily occurrences in a 100-year time period for different recurrence interval discharge is shown in Table 3. The large standard deviations for all states and all recurrence intervals were an indicator of the large variability between catchments. For example, the range in the daily occurrences in 100 years, for the two-year recurrence interval discharge, were 77-382, 62-748, 110-834, 83-254, 102-612 and 97-1854 times for Illinois, Indiana, Iowa, Ohio, Wisconsin and Minnesota, respectively.

Table 3. Calculated number of daily occurrences in a 100-year time period for different recurrence interval discharge events for each state. Standard deviation reported in parentheses. The expected number of occurrences and the number associated with discharges that are $75 \%$ and $125 \%$ of the calculated Log-Pearson Type 3 values are also reported.

\begin{tabular}{|c|c|c|c|c|c|c|}
\hline \multirow{2}{*}{ State } & \multicolumn{6}{|c|}{ Number of Daily Occurrences } \\
\hline & 2-Year & 5-Year & 10-Year & 25-Year & 50-Year & 100-Year \\
\hline Illinois & $174(93)$ & $40(18)$ & $15(6.3)$ & $5.1(3.1)$ & $2.1(1.9)$ & $1.0(1.5)$ \\
\hline Indiana & 209 (175) & $58(49)$ & $24(22)$ & $8.2(6.1)$ & $3.8(2.8)$ & $1.4(1.6)$ \\
\hline Iowa & $245(190)$ & $48(35)$ & $18(11)$ & $5.2(2.5)$ & $2.8(2.2)$ & $0.9(1.1)$ \\
\hline Ohio & $133(53)$ & $34(12)$ & $14(5.4)$ & $6.2(3.0)$ & $2.9(1.9)$ & $1.4(1.1)$ \\
\hline Wisconsin & $210(128)$ & $47(22)$ & $17(9.1)$ & $6.3(4.3)$ & $2.6(1.9)$ & $1.6(1.7)$ \\
\hline Minnesota & $494(351)$ & $94(64)$ & $35(22)$ & $9.4(5.1)$ & $4.1(2.5)$ & $2.0(1.9)$ \\
\hline Mean & $244(165)$ & $54(33)$ & $21(13)$ & $6.7(4.0)$ & $3.1(2.2)$ & $1.4(1.5)$ \\
\hline Expected & 50 & 20 & 10 & 4.0 & 2.0 & 1.0 \\
\hline $75 \%$ Log P Mean & $510(193)$ & $144(45)$ & $70(24)$ & $31(15)$ & $18(11)$ & $11(7.3)$ \\
\hline $125 \%$ Log P Mean & $133(83)$ & $22(12)$ & $7.1(2.8)$ & $1.8(0.7)$ & $0.7(0.3)$ & $0.4(0.2)$ \\
\hline
\end{tabular}




\subsection{Objective 2: Analysis of Calculated versus Expected Occurrences}

As the recurrence interval became larger the difference between the expected number of times and the calculated number of times becomes less. This is shown in Table 4, where the mean ratios of the calculated to expected daily discharges for each state vary from 2.6 to 10.5 for the two-year event compared to a ratio of 0.9 to 1.7 for the 100-year event.

Table 4. The ratio of the calculated to expected number of daily occurrences in a 100-year time period for different recurrence interval discharges.

\begin{tabular}{lcccccc}
\hline \multirow{2}{*}{ Attribute } & \multicolumn{5}{c}{ Ratio of Calculated to Expected Number of Daily Occurrences } \\
\cline { 2 - 7 } & 2-Year & 5-Year & 10-Year & 25-Year & 50-Year & 100-Year \\
\hline Illinois & $3.5(1.8)$ & $2.0(0.9)$ & $1.5(0.6)$ & $1.3(0.8)$ & $1.0(1.0)$ & $1.0(1.5)$ \\
Indiana & $4.2(3.5)$ & $2.9(2.5)$ & $2.4(2.2)$ & $2.1(1.5)$ & $1.9(1.4)$ & $1.4(1.6)$ \\
Iowa & $4.8(3.8)$ & $2.4(1.8)$ & $1.8(1.1)$ & $1.3(0.6)$ & $1.5(1.1)$ & $0.9(1.1)$ \\
Ohio & $2.6(1.1)$ & $1.7(0.6)$ & $1.4(0.5)$ & $1.5(0.7)$ & $1.4(1.0)$ & $1.4(1.1)$ \\
Wisconsin & $4.2(2.6)$ & $2.3(1.1)$ & $1.7(0.9)$ & $1.6(1.1)$ & $1.3(0.9)$ & $1.6(1.7)$ \\
Minnesota & $10.5(7.0)$ & $4.9(3.2)$ & $3.6(2.2)$ & $2.3(1.3)$ & $1.8(1.2)$ & $1.7(1.9)$ \\
\hline Mean & $4.9(4.5)$ & $2.7(2.2)$ & $2.1(1.6)$ & $1.7(1.1)$ & $1.5(1.1)$ & $1.3(1.5)$ \\
\hline 75\% Log P & $10.2(9.1)$ & $7.2(6.6)$ & $7.0(7.5)$ & $7.8(11.1)$ & $9.2(16.9)$ & $11.3(25.9)$ \\
125\% Log P & $2.7(2.9)$ & $1.1(1.1)$ & $0.7(0.6)$ & $0.4(0.4)$ & $0.3(0.5)$ & $0.3(0.8)$ \\
\hline
\end{tabular}

The analysis of reducing the annual peak daily mean discharges by $25 \%$ or increasing them by $25 \%$ showed that if the calculated discharges were under-estimated they deviated even further from the expected discharge and gave unlikely mean ratios of 7 to 11.3 across the range of recurrence interval evaluated (Table 4). In contrast, if the daily discharge were $25 \%$ larger than calculated the ratios become unrealistically low for the more extreme recurrence interval of 10-year to 100-year. However, the two-year and five-year occurrence intervals still had mean ratios larger than one.

\subsection{Objective 3: Evaluation of Statistical Relationships between the Expected and Calculated Frequency of Occurrences}

Regression relationships for each state that are based on the calculated mean ratios in Table 4 are reported in Figure 3. The expected ratio of 1.0 and mean results when the discharge was $25 \%$ larger than the Log-Pearson Type 3 estimates are also shown. Power relationships had R-squared values that ranged from 0.64 to 0.97 . The high R-squared values are misleading as they are based on mean values. This is illustrated in Figure 4 for an analysis with all of the six states and an analysis with the 25 catchments in the state of Indiana. Figure 4A has an R-squared value of 0.9 for the relationship based on the mean of the mean value for all states combined. However, in Figure $4 \mathrm{~B}$ where the relationship was based on the mean values for each state, the R-squared was reduced to 0.6. There was an even more marked reduction in the R-squared value when a relationship was developed with data for each catchment evaluated in a state. Figure $4 \mathrm{C}$ shows the relationship with the mean data for Indiana (R-squared $=0.97$ ) while Figure $4 \mathrm{D}$ shows the relationship based on the 25 individual catchments in Indiana (R-squared $=0.05)$.

When the calculated discharge was decreased by $25 \%$ the mean ratio of calculated to expected occurrences for the 150 catchments and across all recurrence intervals was 10 . There was only one catchment with a ratio less than 1 for the 50-year recurrence interval and four catchments with a ratio less than 1 for the 100-year recurrence interval. In contrast, when the calculated discharges were increased by $25 \%$ the mean ratio of calculated to expected occurrences, for the 150 catchments, and across all recurrence intervals, was 0.9. However, the expected occurrence of the two-year discharge was exceeded by $87 \%$ of the catchment.

The results of the evaluation of the accuracy of the calculated discharges compared to published values are presented in Table 5. A minor difference would be expected, as there were small differences in the published periods of record and those used in our study. The overall mean absolute difference 
between the 850 (six states times 25 catchment times six recurrence intervals less 50 missing values for Indiana) calculated and published discharges was $6.2 \%$. If the overall mean difference was not based on absolute values then the mean difference between the calculated and published discharges was $0.2 \%$. The mean absolute difference for each recurrence interval increased from $5.2 \%$ for the 2-year recurrence interval to $8.5 \%$ for the 100 -year recurrence interval. These results suggest that there is little difference in the simplified Log-Pearson Type 3 approach used in this study and the more rigorous Log-Pearson Type 3 approaches often used in published studies conducted by federal agencies.
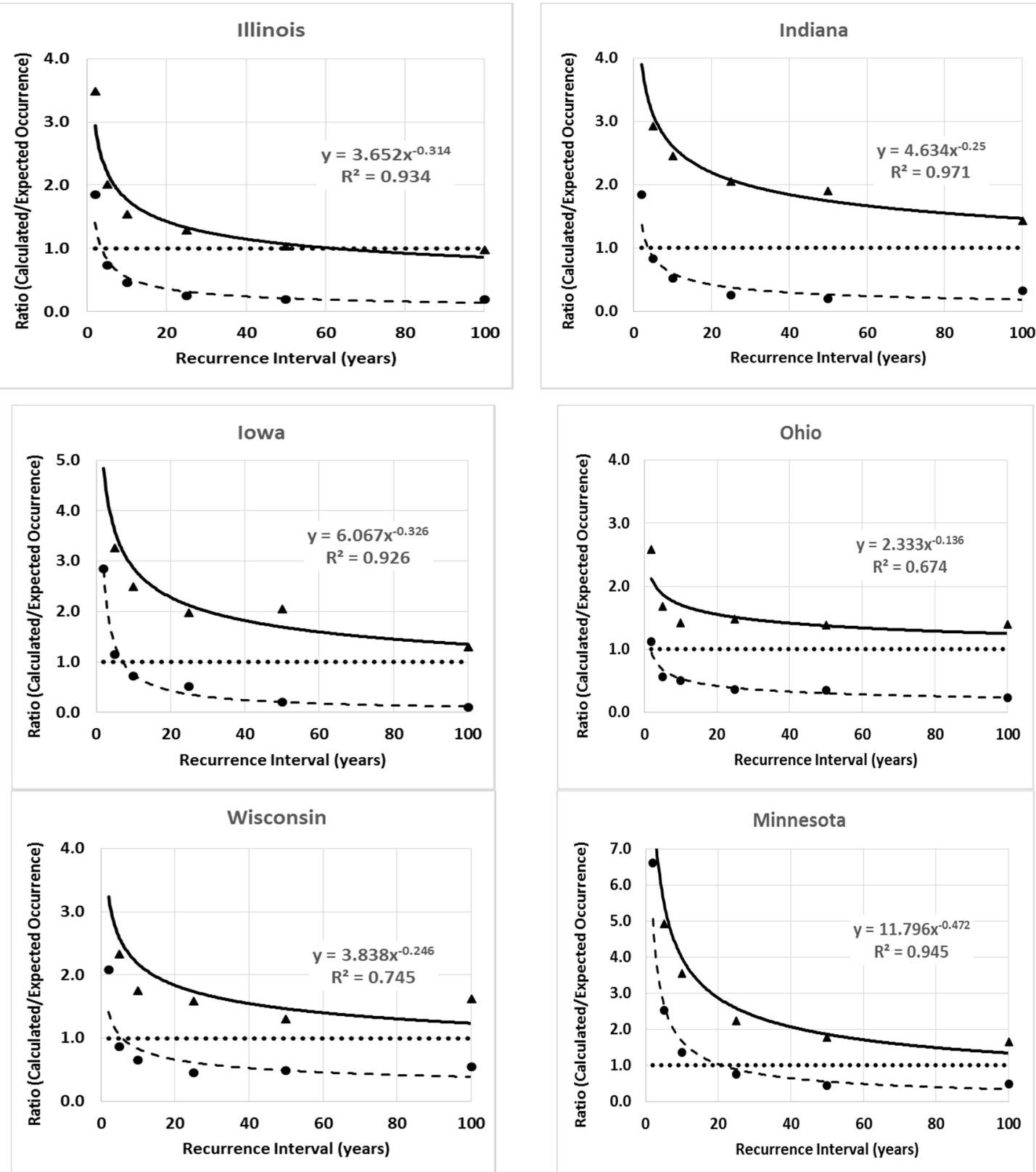

Figure 3. Plots of the ratios of the calculated versus expected occurrences based on the mean discharge of all 25 catchments evaluated for each state (solid triangles). A regression relationship through this data is shown as a solid line together with the relationship and R-squared value. Solid circles and dashed lines are associated with occurrence ratios based on $125 \%$ of the discharges calculated with the Log-Pearson Type 3 analysis. 

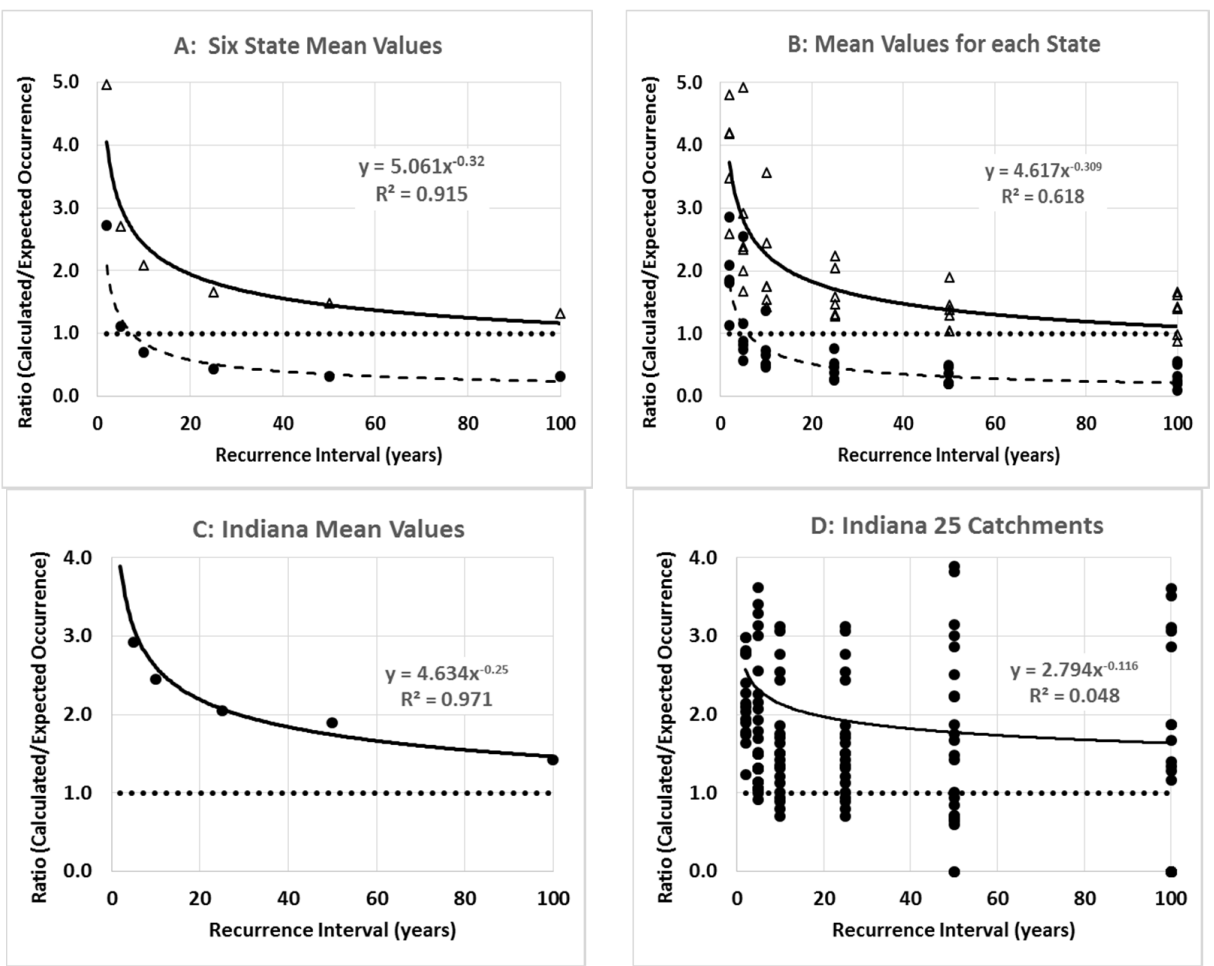

Figure 4. For the Log-Pearson Type 3 approach, the ratio of the calculated versus expected occurrences based on the mean discharge of all 150 catchments evaluated (A); and the mean discharges for the 25 catchments in each state (B). Solid circles and dashed lines are associated with occurrence ratios based on $125 \%$ of the discharges calculated with the Log-Pearson Type 3 analysis. Also shown is the ratio of the calculated versus expected occurrences based on the mean discharge for the 25 catchments evaluated in Indiana (C) and the ratios determined with the discharge for each of the 25 catchments evaluated in Indiana (D).

Table 5. Absolute values of the mean percent difference between the calculated and published discharges for 2-year to 100-year recurrence interval for each state. For Indiana, values for the two-year and five-year values are not reported [45].

\begin{tabular}{cccccccc}
\hline & \multirow{2}{*}{ State Mean $^{\mathbf{1}}$} & \multicolumn{7}{c}{ Mean Absolute Difference $^{\mathbf{2}}$} \\
\cline { 3 - 8 } & & 2-Year & $\mathbf{5 - Y e a r}$ & $\mathbf{1 0 - Y e a r}$ & 25-Year & $\mathbf{5 0 - Y e a r}$ & 100-Year \\
\hline Illinois & 6.2 & 3.4 & 4.5 & 5.2 & 6.5 & 8.2 & 9.2 \\
Indiana & 4.5 & - & - & 3.8 & 3.8 & 4.5 & 5.4 \\
Iowa & 7.5 & 6.0 & 6.7 & 6.2 & 7.1 & 8.6 & 10.3 \\
Minnesota & 7.0 & 5.5 & 5.5 & 5.3 & 6.8 & 8.7 & 10.4 \\
Ohio & 6.7 & 6.0 & 5.6 & 5.9 & 6.6 & 6.9 & 9.5 \\
Wisconsin & 5.3 & 5.3 & 4.5 & 5.9 & 5.2 & 4.7 & 6.3 \\
\hline Mean & $\mathbf{6 . 2}$ & $\mathbf{5 . 2}$ & $\mathbf{5 . 4}$ & $\mathbf{5 . 4}$ & $\mathbf{6 . 0}$ & $\mathbf{6 . 9}$ & $\mathbf{8 . 5}$ \\
\hline
\end{tabular}

Notes: ${ }^{1}$ Reference information for the published discharges is reported in Table 1. Reported in this column is the mean absolute difference, in each state, between the calculated and published discharges for all six recurrence intervals and the 25 catchments in a state. The absolute mean values for all 125 catchments and all recurrence intervals are also reported; ${ }^{2}$ Mean absolute difference for each recurrence interval.

\subsection{Objective 4: Evaluation of the Full Daily Distribution (FDD) Approach}

The FDD approach results, based on the mean of the mean results for the six states, are presented in Table 6. The first column in Table 6 reports the number of catchments used in the analysis. Although the R-squared values for the logarithmic regression relationships, fitted to the calculated Log-Pearson Type 3 discharges, almost always exceeded 0.96, some of the calculated discharges for the frequent 
recurrence intervals were negative and not included in the analysis. Ten catchments had periods of record that were too short to provide results for the largest recurrence interval.

Table 6. Recurrence Interval versus discharge ratios of the full daily distribution (FDD) discharges to those based on an annual series of instantaneous peaks (Peak) and an annual series of peak mean daily discharges (Daily) - based on an analysis of mean results for the six states. Also reported are ratios of the mean daily peaks to the instantaneous peaks. Standard deviations are reported in parentheses.

\begin{tabular}{ccccc}
\hline $\begin{array}{c}\text { Number of } \\
\text { Catchments }\end{array}$ & $\begin{array}{c}\text { Recurrence Interval } \\
\text { Years (std. dev.) }\end{array}$ & $\begin{array}{c}\text { FDD/Peak Ratio } \\
\text { (std. dev.) }\end{array}$ & $\begin{array}{c}\text { FDD/Daily Ratio } \\
\text { (std. dev.) }\end{array}$ & $\begin{array}{c}\text { Daily/Peak Ratio } \\
\text { (std. dev.) }\end{array}$ \\
\hline 106 & $0.79(<0.01)$ & $1.73(0.29)$ & $1.98(0.45)$ & $0.89(0.16)$ \\
124 & $0.99(<0.01)$ & $1.72(0.35)$ & $1.96(0.53)$ & $0.90(0.15)$ \\
143 & $1.38(<0.01)$ & $1.54(0.41)$ & $1.78(0.48)$ & $0.88(0.11)$ \\
150 & $1.92(0.09)$ & $1.31(0.32)$ & $1.61(0.32)$ & $0.81(0.06)$ \\
150 & $4.7(0.22)$ & $1.00(0.18)$ & $1.23(0.14)$ & $0.81(0.06)$ \\
150 & $9.02(0.48)$ & $0.90(0.14)$ & $1.13(0.09)$ & $0.79(0.06)$ \\
150 & $20.81(1.07)$ & $0.84(0.12)$ & $1.09(0.07)$ & $0.77(0.07)$ \\
140 & $36.58(2.67)$ & $0.82(0.08)$ & $1.09(0.04)$ & $0.76(0.07)$ \\
\hline
\end{tabular}

The results in Table 6 and Figure 5 show that for recurrence intervals larger than about 10 years the discharges calculated by the FDD method and those based on an annual series of peak daily means were about $10 \%$ larger. In contrast, for recurrence intervals larger than about 10 years the discharges calculated by the FDD method and those based on an annual series of "instantaneous" peak means were $16 \%$ to $18 \%$ smaller. However, in the recurrence interval range commonly associated with channel-forming discharges ( 0.8 to 2 years), the FDD discharges were $30 \%$ to $98 \%$ larger than discharges obtained by using the Log-Pearson Type 3 method. The results reported in Figure 6 show that the state-to-state variability (Figure 6B) and the catchment-to-catchment variability (Figure 6D) were too large for the regression equations to have any general application.
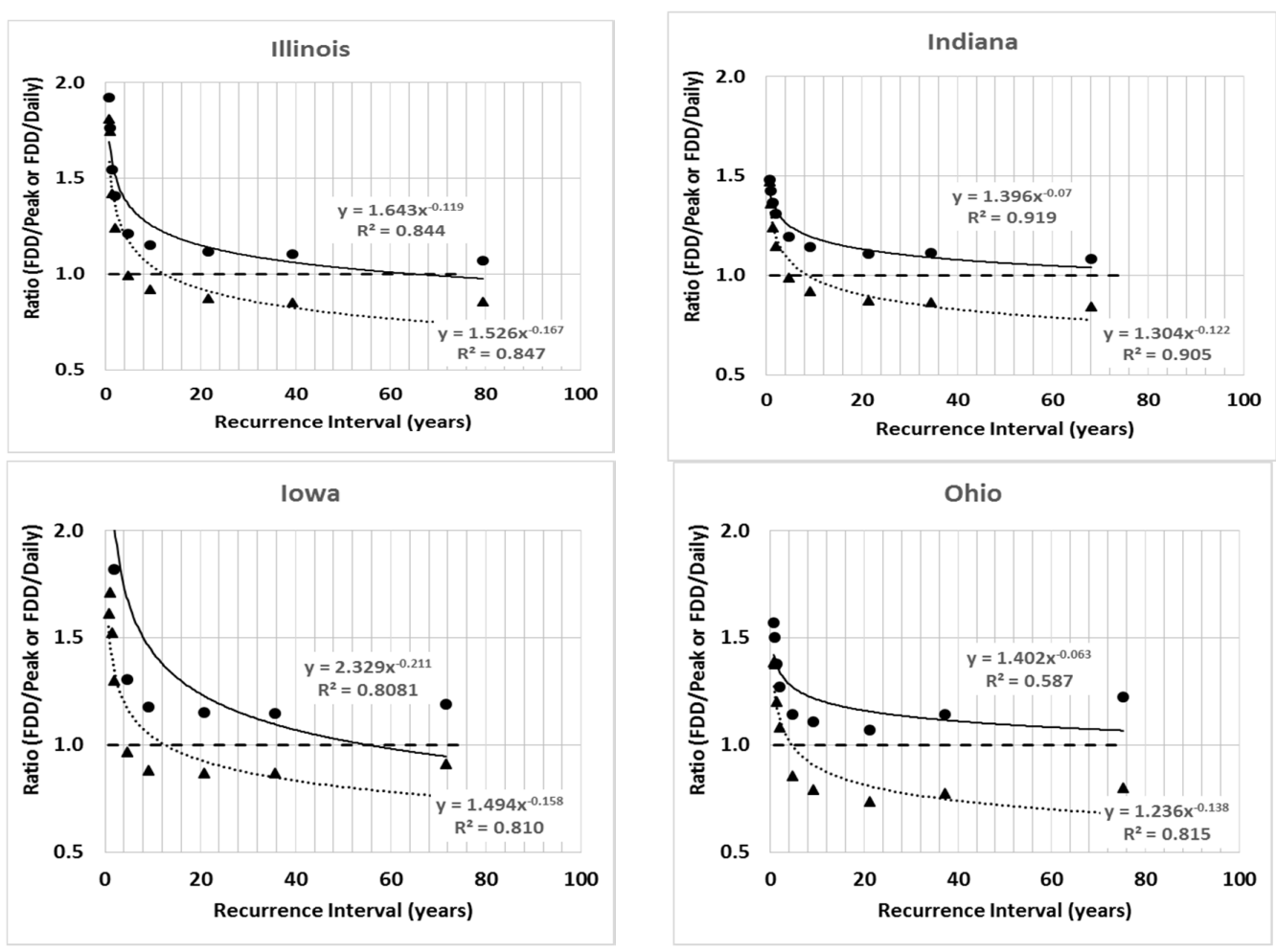

Figure 5. Cont. 

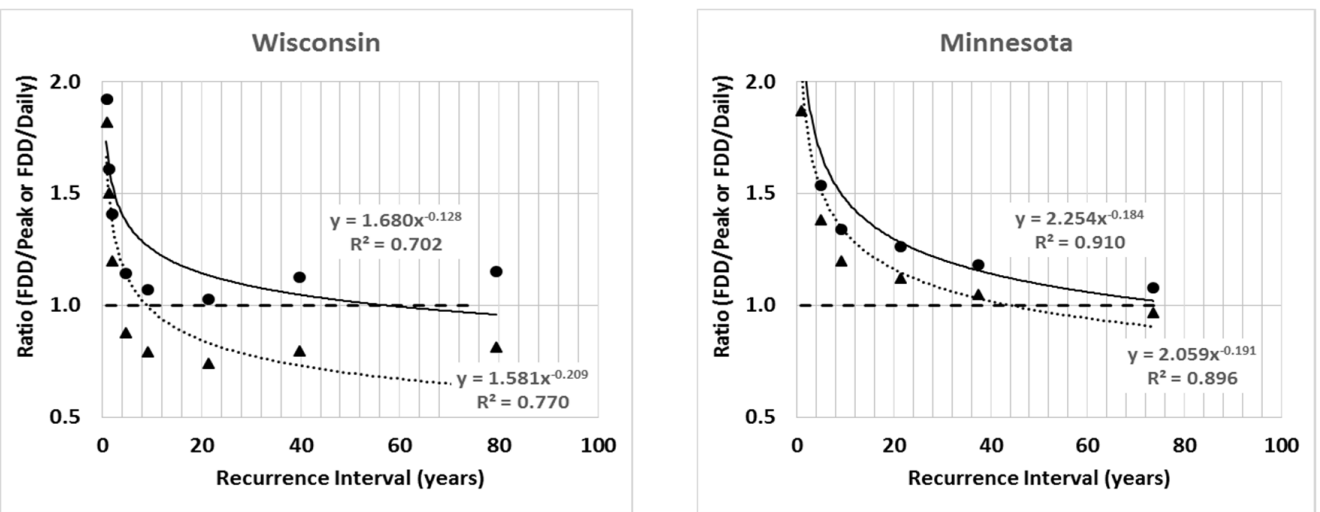

Figure 5. For different recurrence intervals, the ratio of calculated full daily distribution (FDD) discharges to the Log-Pearson Type 3 results for an annual series of instantaneous peaks (solid circles) and peak daily means (solid triangles). The values are based on data from Table 6 . The solid and dotted lines are regressions lines associated with the solid circles and solid triangles, respectively.
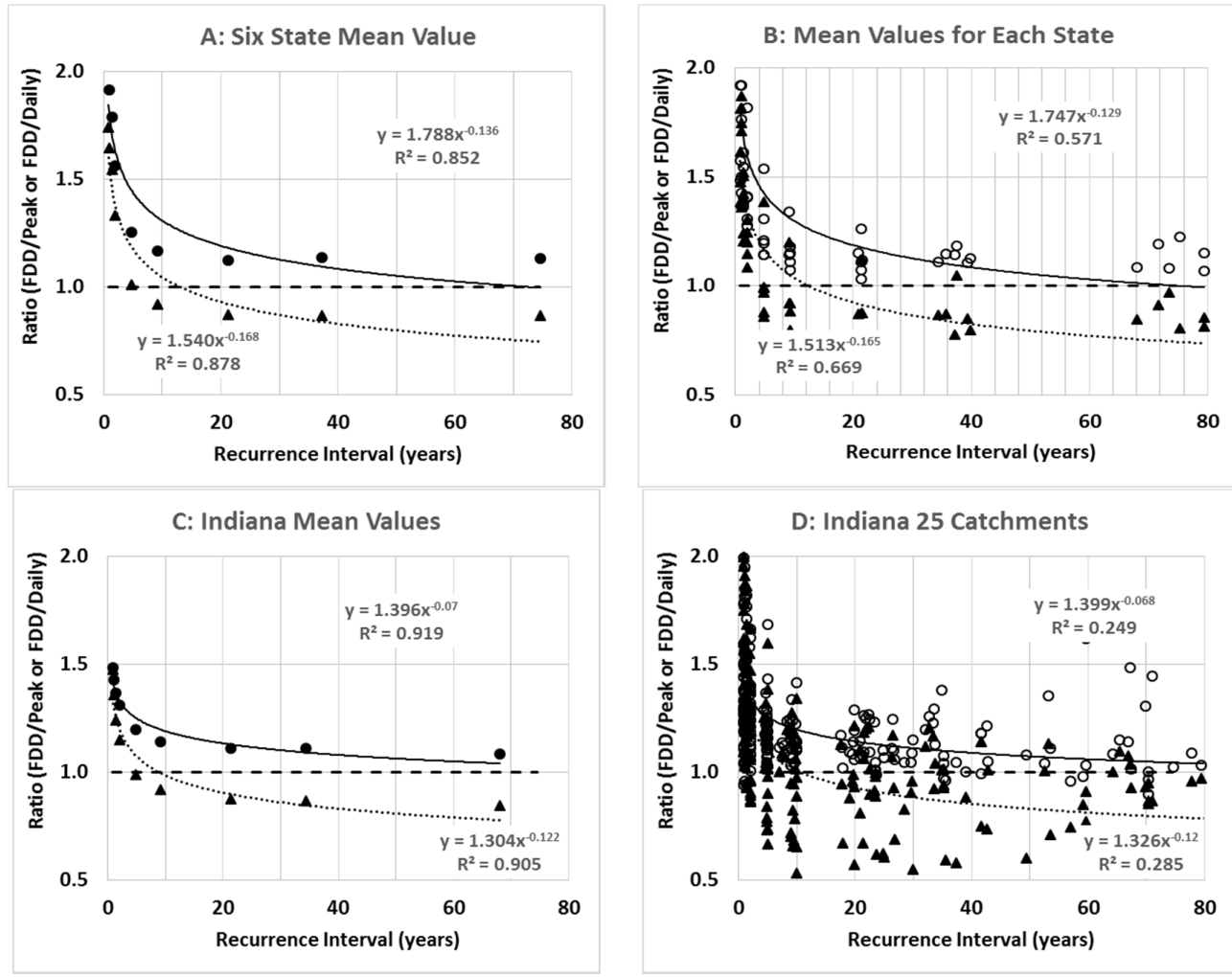

Figure 6. For the FDD approach, the ratio of the calculated versus expected occurrences based on the mean discharge of all 150 catchments evaluated (A); and the mean discharges for the 25 catchments in each state $(\mathbf{B})$. In $(\mathbf{A}, \mathbf{B})$, the circles and solid lines are associated with the FDD/Peak ratios and the solid triangles and dashed lines are associated with the FDD/Daily ratios. Also shown are the ratio of the calculated versus expected occurrences based on the mean discharge for the 25 catchments evaluated in Indiana (C); and the ratios determined with the discharge for each of the 25 catchments evaluated in Indiana (D). Data symbols and lines are the same as in $(\mathbf{A}, \mathbf{B})$.

\section{Discussion}

The evidence from this study suggests that the frequency of channel-forming discharges that have a recurrence interval less than five years are likely to occur much more frequently than statistical 
expectations. The calculated smallest number of occurrences in 100 years for the two-year recurrence interval daily discharge was 62 times for one of the catchments, while the highest number of occurrences for the two-year event was 1854 days in 100 years. On average, a two-year or larger discharge was calculated to occur about 2.5 days annually.

Based on an annual series of peak daily means, the ratio of the calculated to the expected mean number of occurrences were highly correlated to the recurrence interval with the exception of the results for Ohio (R-squared $=0.64$, see Figure 3). However, when the state-to-state or catchment-to-catchment variability was considered (Figure 3) the correlation was too low for scientific purposes. The analysis based on discharges $25 \%$ larger or smaller than those obtained from the Log-Pearson Type 3 analysis indicated that the discharges were generally unlikely to be much smaller or larger than the calculated values.

The results obtained with the full daily distribution (FDD) approach were in general agreement with a study conducted by Endreny [32] with data for 46 bankfull surveyed gauges in Maryland, North Carolina, and New York. Using a flow duration approach with a daily peak series he found that on average the bankfull discharge occurred 2.1 days annually and a maximum mean number of times of 13.2 days annually. He determined that by using either an annual instantaneous peak series or an annual daily peak series the recurrence interval of the bankfull discharge was about 1.4 years and concluded that use of a flow duration analysis helped to describe that bankfull discharges occur more than one time or one day annually. Navratil et al. [50], in a study of 16 gravel-bed rivers in France, evaluated five different methods to identify bankfull and determined that the mean annual duration of occurrence varied from 4.5 days to 11.5 days depending on the method. One of their conclusions was that the annual maximum flood (AMF) analysis should be avoided.

Using the FDD method for each catchment the maximum recurrence interval was limited by the number of years in the period of record. For example, for the results reported in Table 7, the maximum recurrence interval was 89 years.

Table 7. Comparison of FDD method calculated exceedance and expected occurrences (reported as days) for different recurrence intervals. The difference between the calculated exceedances and expected occurrences were the number of discharge values in the bin with the maximum discharge shown. Reported results are for the Sandusky River, near Fremont Ohio, by using K values of 0.5 and 20 in Equation (1).

\begin{tabular}{|c|c|c|c|c|c|c|c|}
\hline \multicolumn{4}{|c|}{$\mathrm{K}=20$ and Bin Size of $0.53 \mathrm{~m}^{3} / \mathrm{s}$} & \multicolumn{4}{|c|}{$\mathrm{K}=0.5$ and Bin Size of $21.25 \mathrm{~m}^{3} / \mathrm{s}$} \\
\hline $\begin{array}{c}\text { RI } \\
\text { (years) }\end{array}$ & $\begin{array}{c}\text { Discharge } \\
\left(\mathrm{m}^{3} / \mathrm{s}\right)\end{array}$ & $\begin{array}{l}\text { Calculated } \\
\text { (days) }\end{array}$ & $\begin{array}{l}\text { Expected } \\
\text { (days) }\end{array}$ & $\begin{array}{c}\mathrm{RI} \\
\text { (years) }\end{array}$ & $\begin{array}{c}\text { Discharge } \\
\left(\mathrm{m}^{3} / \mathrm{s}\right)\end{array}$ & $\begin{array}{l}\text { Calculated } \\
\text { (days) }\end{array}$ & $\begin{array}{c}\text { Expected } \\
\text { (days) }\end{array}$ \\
\hline 0.59 & 380 & 146 & 152 & 0.56 & 435 & 133 & 160 \\
\hline 0.79 & 413 & 108 & 112 & 0.67 & 458 & 94 & 133 \\
\hline 0.98 & 439 & 86 & 91 & 0.95 & 481 & 77 & 94 \\
\hline 1.46 & 462 & 59 & 61 & 1.48 & 527 & 48 & 60 \\
\hline 1.98 & 487 & 44 & 45 & 1.85 & 550 & 40 & 48 \\
\hline 4.94 & 598 & 17 & 18 & 4.94 & 641 & 14 & 18 \\
\hline 9.89 & 652 & 8 & 9 & 9.89 & 710 & 7 & 9 \\
\hline 22.25 & 765 & 3 & 4 & 22.25 & 779 & 2 & 4 \\
\hline 44.50 & 946 & 1 & 2 & 44.50 & 962 & 1 & 2 \\
\hline 89.00 & 1020 & 0 & 1 & 89.00 & 1031 & 0 & 1 \\
\hline
\end{tabular}

The FDD results were a function of the $\mathrm{K}$ value of 20 used in the study. In Table 7, calculated values are the number of exceedances and expected values are the number of occurrences (days) for a RI. The difference between the calculated exceedances and expected occurrences were the number of discharge values in the bin with the maximum discharge shown. For example, with K equal to 20, there were 146 discharge values larger than $380 \mathrm{~m}^{3} / \mathrm{s}$ and six discharge values (152-146) in the bin containing discharges in the range 379.47 to $380 \mathrm{~m}^{3} / \mathrm{s}$. The expected value of 152 is 89 years/ 0.586 years $(0.586$ is 
round to 0.59 in Table 7). Using a K value of 20, as shown in Figure 7B, resulted in smaller bin discharge ranges than for a $\mathrm{K}$ value of 0.5 (Figure $7 \mathrm{~A}$ ) and a better representation of the frequency distribution of different magnitude discharges. For example with $\mathrm{K}$ values of 20 and 0.5 the 4.94 -year recurrence interval discharges are $598 \mathrm{~m}^{3} / \mathrm{s}$ and $641 \mathrm{~m}^{3} / \mathrm{s}$, respectively. For the Sandusky River catchment, with a period of record of 89 years, a K value of 20 gave 1780 bins (20 times 89 ) while a K value of 0.5 only gave 45 bins. For a $\mathrm{K}$ value of 20, the average number of values in each bin was 18.3 for all the catchments while a $\mathrm{K}$ value of 0.5 had an average of 722 values.

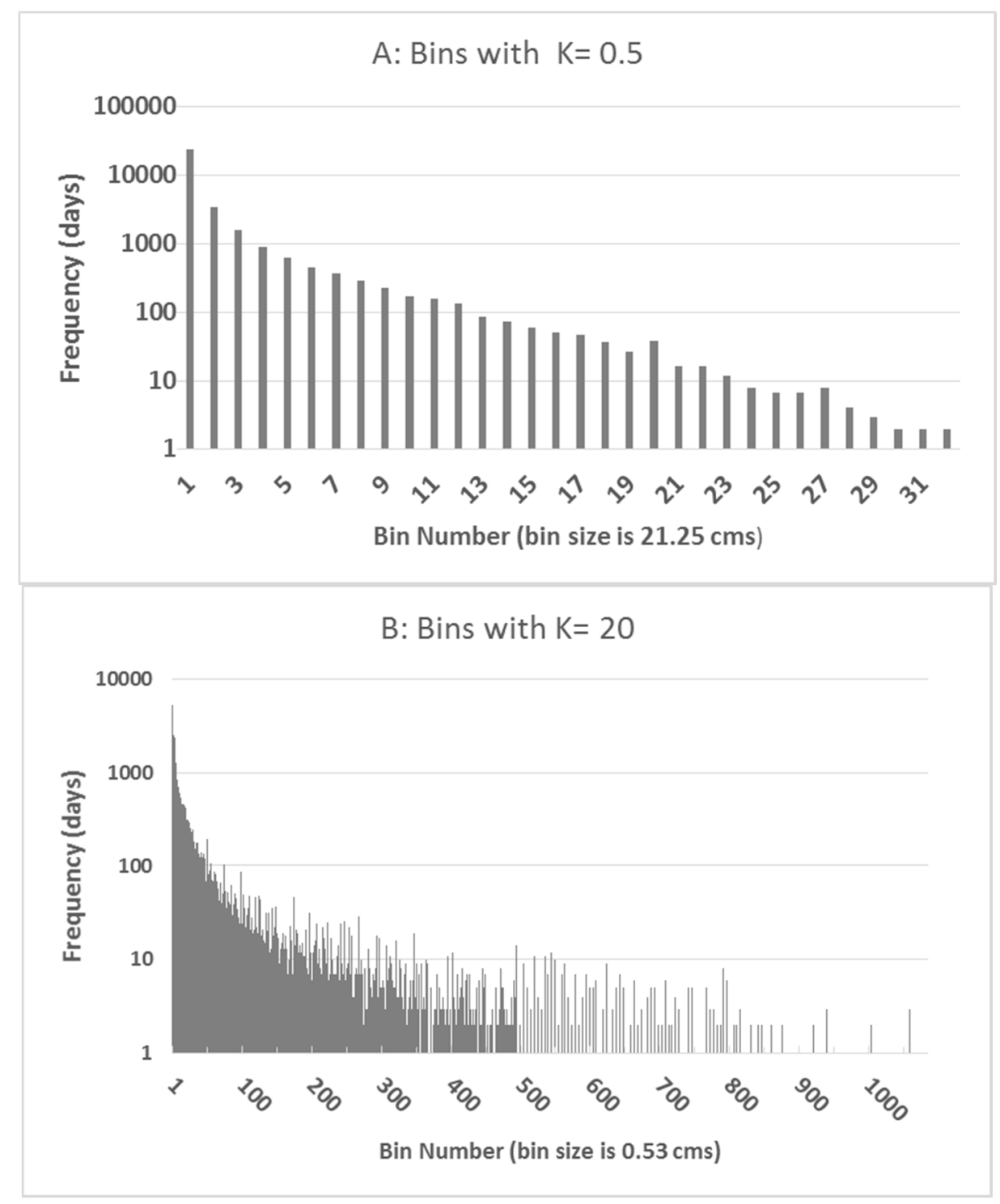

Figure 7. Histograms with $K=0.5$ (A) and $K=20$ (B) for the Sandusky River, near Fremont Ohio. A bin with a bin number of 1 has all discharges less than $21.25 \mathrm{~m}^{3} / \mathrm{s}(\mathrm{K}=0.5)$ and $0.53 \mathrm{~m}^{3} / \mathrm{s}(\mathrm{K}=20)$. A bin with a bin number of $10(\mathrm{~K}=0.5)$ ) contains discharges between approximately 229.0 and $229.07 \mathrm{~m}^{3} / \mathrm{s}$. A bin with a bin number of $400(\mathrm{~K}=20)$ contains discharges between approximately 229.07 and $229.64 \mathrm{~m}^{3} / \mathrm{s}$.

The strength of the FDD approach was that the calculated number of occurrence were always in close agreement with the expected number of occurrences. The FDD approach does, therefore, provide a useful approach for discharge versus recurrence interval relationships in both the range of channel-forming discharges and also for extreme floods. However, it is less useful for extreme floods 
as the maximum recurrence interval that can be calculated by the method is the number of years in the period of record.

The number of occurrences of a discharge associated with a recurrence interval raises the question as to what is the meaning of the term channel-forming discharge. It might be more appropriately called a channel-forming threshold discharge. Discharges below the threshold are sufficient to transport sediment and to shape the channel geometry-geomorphic work associated with scour and deposition. The function of discharges above the threshold will depend on floodplain connectivity and the size of the floodplain. What is important to note is that, statistically, all discharges higher than the threshold are included in the statistical definition. Therefore, in mountain streams where the banks will generally not be flat and in locations where the floodplain is small, the functional usefulness of basing a restoration design just on a channel-forming discharge must be questionable. A number of approaches based on sediment transport, hydraulics, and dynamics of the system have more merit $[1,51]$ than using an uncertain estimate of the channel-forming discharge.

Other implications of the statistical meaning and statistical uncertainty of channel-forming discharges for river restoration are unclear. For example, He and Wilkerson [52] determined that in some cases regional bankfull geometry relationship can be better estimated as a function of the 2-year recurrence interval discharge or this discharge and the drainage area. If that approach is used it would be desirable to have a standard method for determining the 2-year recurrence interval discharge.

In the United States, a commonly used Internet tool for ungauged sites is the USGS StreamStats Method (http://water.usgs.gov/osw/streamstats/) that, based on regional regression equations, can provide discharge versus recurrence interval estimates for any location in the more than 30 states where StreamStats is operational. A problem with the approach is that reported errors in a discharge estimate usually range from $30 \%$ to $50 \%$. Like other prediction methods, it is necessary to calibrate the method with data from the nearest suitable river gauge [33,53]. Typically, this is done by developing calibration variables based on first using discharge data at the river gauge and then relating the results to a Log-Pearson Type 3 analysis of an annual series of maximum instantaneous peaks as that data are readily available from the USGS-NWIS state websites. The results of this study indicated that calibration with an FDD analysis of mean daily discharges might be more appropriate. However, this creates an inconsistency in methodology as hydrologic prediction methods usually estimate peak discharges not mean daily discharges.

\section{Conclusions}

Using a Log-Pearson Type 3 statistical method with an annual series of instantaneous peaks or peak daily mean values provided discharge versus recurrence interval results that were consistent with flood events with recurrence intervals larger than 25 years. However, for more frequent recurrence intervals in the range of channel-forming discharges (less than five years) calculated discharges occured several times more frequently than statistical expectations.

With the FDD approach, the calculated number of occurrences associated with a recurrence interval were similar to the expected number of occurrences. This was not the case with the Log-Pearson Type 3 method. The FDD approach can easily be used where long periods of record of daily discharge data are available as it uses analysis functions commonly available in spreadsheets and statistical software. A strength of the method is that it adjusts the number of bins and discharge range of the bins as a function of the period of record and the magnitude of the measured discharges.

Further work is needed to evaluate how skew values in the Log-Pearson Type 3 method could be modified to better account for statistical inconsistencies in the range of channel-forming discharges. In addition, where discharge data are not available, work is needed to determine how peak flow prediction methods might be modified. The importance of the current inconsistencies in determining recurrence intervals or discharges associated with channel-forming discharges is not clear and requires further work. However, we speculate, based on the literature that suggests a high frequency of river 
restorations do not perform as expected, that incorrect estimates of the channel-forming discharge could be a contributing factor.

Acknowledgments: The work presented in this manuscript was funded in part by the Ohio Water Development Authority (OWDA), the Ohio Agricultural Research and Development Center (OARDC), the College of Food Agricultural and Environmental Sciences and the Department of Food, Agricultural and Biological Engineering at The Ohio State University. Jessica D'Ambrosio assisted with the editing of the manuscript.

Author Contributions: Molly Moran initiated this work as part of her graduate studies. She proposed the promising FDD approach and developed most of the Excel template tools. Part way through the study, she switched majors and all of the analysis that is presented in the manuscript was conducted by Andy Ward who was also the lead author in preparing the manuscript.

Conflicts of Interest: The authors declare no conflict of interest.

\section{References}

1. Bernhardt, E.S.; Palmer, M.A.; Allan, J.D.; Alexander, G.; Barnas, K.; Brooks, S.; Carr, J.; Clayton, S.; Dahm, C.; Follstad-Shah, J.; et al. Restoration of U.S. Rivers: A national Synthesis. Science 2005, 308, 636-637. [CrossRef] [PubMed]

2. Hey, R. Fluvial Geomorphological Methodology for Natural Stable Channel Design. J. Am. Water Resour. 2006, 42, 357-372. [CrossRef]

3. Rosgen, D.L. The Rosgen Geomorphic Approach for Natural Channel Design. In Stream Restoration Design. National Engineering Handbook Part 654; U.S. Department of Agriculture, National Resources Conservation Service: Washington, DC, USA, 2007.

4. Lave, R. The controversy over natural channel design: Substantive explanations and potential avenues for resolution. J. Am. Water Resour. 2009, 45, 1519-1532. [CrossRef]

5. Simon, A.; Doyle, M.; Kondolf, M.; Shields, F.D., Jr.; Rhoads, B.; McPhillips, M. Critical evaluation of how the Rosgen classification and associated "natural channel design" methods fail to integrate and quantify fluvial processes and channel response. J. Am. Water Resour. 2007, 43, 1117-1131. [CrossRef]

6. Doyle, M.W.; Shields, F.D.; Boyd, K.F.; Skidmore, P.B.; Dominick, D. Channel-forming discharge selection in river restoration design. J. Hydraul. Eng. 2007, 133, 1-7. [CrossRef]

7. Wolman, M.G.; Miller, J.P. Magnitude and frequency of forces in geomorphic processes. J. Geol. 1960, 68, 54-74. [CrossRef]

8. Goodwin, P. Analytical solutions for estimating effective discharge. J. Hydraul. Eng. 2004, 130, 729-738. [CrossRef]

9. Emmett, W.W.; Wolman, M.G. Effective discharge and gravel-bed rivers. Earth Surf. Proc. Landf. 2001, 26, 1369-1380. [CrossRef]

10. Torizzo, M.; Pitlick, J. Magnitude-frequency of bed load transport in mountain streams in Colorado. J. Hydrol. 2004, 290, 137-151. [CrossRef]

11. Powell, G.E.; Mecklenburg, D.; Ward, A. Evaluating channel-forming discharges: A study of large rivers in Ohio. Trans. ASABE 2006, 49, 35-46. [CrossRef]

12. Dury, G.H. Discharge prediction, present and former, from channel dimensions. J. Hydrol. 1976, 30, 219-245. [CrossRef]

13. Leopold, L.B.; Wolman, M.G.; Miller, J.P. Fluvial Processes in Geomorphology; W.H. Freeman: San Francisco, CA, USA, 1964; p. 522.

14. Williams, G.; Arnett, P. Bank-full discharge of rivers. Water Resourc. Res. 1978, 14, 1141-1154. [CrossRef]

15. Andrews, E.D.; Nankervis, J.M. Effective discharge and the design of channel maintenance flows for gravel-bed rivers. In Natural and Anthropogenic Influences in Fluvial Geomorphology; Costa, J.E., Miller, A.J., Potter, K.W., Wilcock, P.R., Eds.; Geophysical Monograph Series; American Geophysical Union: Washington, DC, USA, 1995; Volume 89, pp. 151-164.

16. Simon, A.; Dickerson, W.; Heins, A. Suspended-sediment transport rates at the 1.5-year recurrence interval for ecoregions of the United States: Transport conditions at the bankfull and effective discharge? Geomorphology 2004, 58, 243-246. [CrossRef]

17. Lenzi, M.A.; Mao, L.; Comiti, F. Effective discharge for sediment transport in a mountain river: Computational approaches and geomorphic effectiveness. J. Hydrol. 2006, 326, 257-276. [CrossRef] 
18. Biedenharn, D.S.; Thorne, C.R.; Soar, P.J.; Hey, R.D.; Watson, C.C. Effective discharge calculation guide. Int. J. Sediment Res. 2001, 16, 445-459.

19. Vogel, R.M.; Stedinger, J.R.; Hooper, R.P. Discharge indices for water quality loads. Water Resour. Res. 2003, 39. [CrossRef]

20. Ferro, V.; Paolo, P. Identifying a dominant discharge for natural rivers in southern Italy. Geomorphology 2012, 139-140, 313-321. [CrossRef]

21. USGS. The "100-Year Flood"; Fact Sheet 229-96; USGS Washington: Tacoma, WA, USA, 1996; p. 2.

22. Nolan, K.M.; Lisle, T.E.; Kelsey, H.M. Bankfull discharge and sediment transport in northwestern California. In Erosion and Sedimentation in the Pacific Rim; IAHS Publication 165; International Association of Hydrological Sciences: Wallingford, UK, 1987; pp. 439-450.

23. Sichingabula, H.M. Magnitude-frequency characteristics of effective discharge for suspended sediment transport, Fraser River, British Columbia, Canada. Hydrol. Process. 1999, 13, 1361-1380. [CrossRef]

24. Whiting, P.J.; Stamm, J.F.; Moog, D.B.; Orndorff, R.L. Sediment transporting flows of headwater streams. GSA Bull. 1999, 111, 450-466. [CrossRef]

25. MacRae, C.R. Experience from morphological research on Canadian streams: Is control of the 2-year frequency runoff event the best basis for stream channel protection? In Effects of Catchment Development and Management on Aquatic Systems; Roesner, L., Ed.; American Society of Civil Engineers: Reston, VA, USA, 1996; pp. 144-160.

26. Gomez, B.; Coleman, S.E.; Sy, V.W.K.; Peacock, D.H.; Kent, M. Channel change, bankfull and effective discharges on a vertically accreting, meandering, gravel-bed river. Earth Surf. Proc. Landf. 2007, 32, 770-785. [CrossRef]

27. Annable, W.K.; Lounder, V.G.; Watson, C.C. Estimating channel-forming discharge in urban watercourses. River Res. Appl. 2011, 27, 738-753. [CrossRef]

28. Andrews, E.D. Effective and bankfull discharges of streams in the Yampa River basin, Colorado and Wyoming. J. Hydrol. 1980, 46, 311-330. [CrossRef]

29. Interagency Committee on Water Data (IACWD). Guidelines for Determining Flood Flow Frequency; Bulletin 17B of the Hydrology Subcommittee; U.S. Department of the Interior Geological Survey, Office of Water Data Coordination: Reston, VA, USA, 1982.

30. Water Resources Council Hydrology Committee. A Uniform Techniques for Determining Flood Flow Frequencies; Bulletin No. 15; Water Resources Council: Washington, DC, USA, 1967.

31. Stedinger, J.R.; Griffis, V.W. Flood Frequency Analysis in the United States: Time to Update. J. Hydrol. Eng. 2008, 13, 199-204. [CrossRef]

32. Endreny, T.A. Estimation of channel bankfull occurrence from instantaneous discharge data. J. Hydrol. Eng. 2007, 12, 524-531. [CrossRef]

33. McCuen, R.H.; Galloway, K.E. Record length requirements for annual maximum flood series. J. Hydrol. Eng. 2010, 15, 704-707. [CrossRef]

34. Ward, A.D.; Trimble, S.W.; Burckhard, S.R.; Lyon, J.G. Environmental Hydrology, 3rd ed.; CRC Press, Inc.: Boca Raton, FL, USA, 2015; p. 663.

35. Petit, F.; Pauquet, A. Bankfull discharge recurrence interval in gravel-bed rivers. Earth Surf. Proc. Landf. 1997, 22, 685-693. [CrossRef]

36. Keast, D.; Ellison, J. Magnitude frequency analysis of small floods using the annual and partial series. Water 2013, 5, 1816-1829. [CrossRef]

37. Madsen, H.; Rasmussen, P.F.; Rosbjerg, D. Comparison of annual maximum series and partial duration series methods for modeling extreme hydrologic events: 1. At-site modeling. Water Resour. Res. 1997, 33, 747-757. [CrossRef]

38. The Institution of Engineers Australia. Australian Rainfall and Runoff: A Guide to Flood Estimation; Institution of Engineers Australia: Canberra, Australia, 1987.

39. Langbein, W.B. Annual floods and the partial-duration flood series. Trans. Am. Geophys. Union 1949, 30, 879-881. [CrossRef]

40. Claps, P.; Laio, F. Can continuous streamflow data support flood frequency analysis? An alternative to the partial duration series approach. Water Resour. Res. 2003, 39. [CrossRef]

41. Doyle, M.W.; Stanley, E.H.; Strayer, D.L.; Jacobson, R.B.; Schmidt, J.C. Effective discharge analysis of ecological processes in streams. Water Resour. Res. 2005, 41, 1-16. [CrossRef] 
42. Crowder, D.W.; Knapp, H.V. Effective discharge recurrence intervals in Illinois streams. Geomorphology 2005, 64, 167-184. [CrossRef]

43. Quader, A.; Guo, Y. The relative importance of hydrological and sediment-transport characteristics affecting the effective discharge of small urban streams in southern Ontario. J. Hydrol. Eng. 2009, 14, 698-710. [CrossRef]

44. Soong, D.T.; Ishii, A.L.; Sharpe, J.B.; Avery, C.F. Estimating Flood-Peak Discharge Magnitudes and Frequencies for Rural Streams in Illinois; Scientific Investigations Report 2004-5103; U.S. Geological Survey: Reston, VA, USA, 2004; p. 147.

45. Knipe, D.; Rao, A.R. Estimation of Peak Discharges of Indiana Streams by Using Log-Pearson (III) Distribution; FHWA/IN/JTRP-2005/1; School of Civil Engineering, Purdue University: West Lafayette, IN, USA, 2005; p. 194.

46. Eash, D.A.; Barnes, K.K.; Veilleux, A.G. Methods for Estimating Annual Exceedance-Probability Discharges for Streams in Iowa, Based on Data through Water Year; Scientific Investigations Report 2013-5086; U.S. Geological Survey: Reston, VA, USA, 2010; p. 63.

47. Lorenz, D.L.; Sanocki, C.A.; Kocian, M.J. Techniques for Estimating the Magnitude and Frequency of Peak Flows on Small Streams in Minnesota Based on Data through Water Year 2005; U.S. Geological Survey Scientific Investigations Report 2009-5250; U.S. Geological Survey: Reston, VA, USA, 2010; p. 54.

48. Koltun, G.F. Techniques for Estimating Flood-Peak Discharges of Rural, Unregulated Streams in Ohio, 2nd ed.; Water-Resources Investigations Report 2003-4164; U.S. Geological Survey: Denver, CO, USA, 2003; p. 75.

49. Walker, J.F.; Krug, W.R. Flood-Frequency Characteristics of Wisconsin Streams; USGS Water-Resources Investigations Report 03-4250; U.S. Geological Survey: Denver, CO, USA, 2003; p. 37.

50. Navratil, O.; Albert, M.-B.; Hérouin, E.; Gresillon, J.-M. Determination of bankfull discharge magnitude and frequency: comparison of methods on 16 gravel-bed river reaches. Earth Surf. Process. Landf. 2006, 31, 1345-1363. [CrossRef]

51. Wohl, E.; Angermeier, P.L.; Bledsoe, B.; Kondolf, G.M.; MacDonnell, L.; Merritt, D.M.; Palmer, M.A.; Poff, N.L.; Tarboton, D. River restoration. Water Resour. Res. 2005, 41, W10301. [CrossRef]

52. He, L.; Wilkerson, G.V. Improved bankfull channel geometry prediction using two-year return-period discharge. J. Am. Water Resour. 2011, 47, 1298-1316. [CrossRef]

53. Moore, R.J.; Bell, V.A.; Cole, S.J.; Jones, D.A. Rainfall-Runoff and Other Modelling for Ungauged/Low-Benefit Locations; R\&D Technical Report SC030227/SR1; Environment Agency: Bristol, UK, 2007; p. 247. 